\title{
Evidence for the Differential Secretion of Oxytocin and Vasopressin in Man*
}

\author{
Eduardo Gaitan, Edgard Cobo, and Matilde Mizrachi \\ (From the Section of Endocrinology, Department of Medicine, and the Department of \\ Obstetrics and Gynecology, University del Valle, School of \\ Medicine, Cali, Colombia, South America)
}

In the present study we have attempted to answer the question whether vasopressin and oxytocin are secreted together or independently. This subject has been a matter of controversy during the past 35 years. The great variety of methods used in measuring oxytocin and vasopressin activities, the variety of animal species studied, and the variety and magnitude of stimuli employed in different studies make it very difficult to compare results and to draw conclusions as to whether or not there may be independent release of these two neurohypophyseal hormones (1-5).

The studies to be described in the present report have been performed in conscious women in whom several relatively mild stimuli known to act on the neurohypophysis were applied under carefully controlled conditions. In the absence of adequate methods for assaying oxytocin and vasopressin directly in plasma, both hormones were assayed by indirect methods that have gained general acceptance. The results strongly suggest that under appropriate conditions oxytocin and vasopressin are released independently of each other by the human neurohypophysis.

\section{Methods}

Studies in 29 women were carried out during the last weeks of pregnancy ( 36 to 40 weeks) or during the first week of puerperium, or both.

In preparation for the measurement of vasopressin activity, a constant degree of overhydration was induced by the oral administration of 10 to $20 \mathrm{ml}$ of water per $\mathrm{kg}$ of body weight or the intravenous administration of a similar amount as $5 \%$ glucose in water. Urine was collected through an indwelling catheter every 15 min-

* Submitted for publication January 27, 1964 ; accepted August 10, 1964.

Presented at the Forty-fifth Annual Meeting of the Endocrine Society, Atlantic City, N. J., June 13, 1963. Supported by grant 59028 from the Rockefeller Foundation. utes. Venous blood was collected for use in the determination of free water clearance $\left(\mathrm{C}_{\mathrm{H}_{2} \mathrm{O}}\right)$, solute clearance $\left(\mathrm{C}_{\mathrm{osm}}\right)$, and creatinine clearance $\left(\mathrm{C}_{\mathrm{Cr}}\right)$. Osmolality was monitored by the freezing point depression method (Fiske osmometer), and creatinine was measured by the method of Bonsnes and Taussky (6). An increase in urine osmolality (decrease in $\mathrm{C}_{\mathrm{H}_{2} \mathrm{O}}$ ) without significant changes in $\mathrm{C}_{\mathrm{Cr}}$ and $\mathrm{C}_{\mathrm{osm}}$ was taken as evidence of vasopressin activity (antidiuretic response) (7).

In late pregnancy, oxytocic activity was assayed by monitoring intrauterine pressure by the method of Caldeyro-Barcia and associates $(8,9)$. A thin polyethylene catheter was inserted into the uterine cavity through the anterior abdominal wall and connected to a pressure transducer and a Sanborn Poly-Viso recorder. This procedure has, with long experience, proved to be innocuous. Uterine or "oxytocic" activity was expressed in Montevideo units, representing the product of the amplitude of the contractions in millimeters of mercury multiplied by the frequency of the contractions during a given period $(8,9)$. During the puerperium, oxytocin was assayed by the measurement of intramammary pressure or "milk-ejecting pressure" by the method of Sica-Blanco and co-workers (10). The procedure and equipment were similar to those used for measuring uterine activity. The outer orifice of a mammary duct was located by gentle manual expression of the nipple, and a lacrimal duct explorer (no. $00-0$ ) was introduced to dilate the duct. Then, a polyethylene catheter (i.d. 023 inch, o.d. .038 inch) filled with water and connected to the pressure detecting device was introduced about 1 to 2 inches and left in place in the dilated duct. The area under the curves recorded was measured and expressed in square inches. This method is more specific and more sensitive than the uterine test for oxytocin activity.

Stimuli used were suckling and duct dilatation of a mammary gland, nicotine (as salicylate), and 3\% sodium chloride.

Exogenous hormones used as assay reference standards were synthetic oxytocin (Syntocinon) and vasopressin (aqueous Pitressin).

To evaluate the statistical significance of the differences between control values and values during antidiuretic and oxytocic/milk-ejecting responses to stimuli, the Student $t$ test was used. In this analysis, the data on oxytocic and milk-ejecting responses were handled together, but as they were originally expressed in dif- 


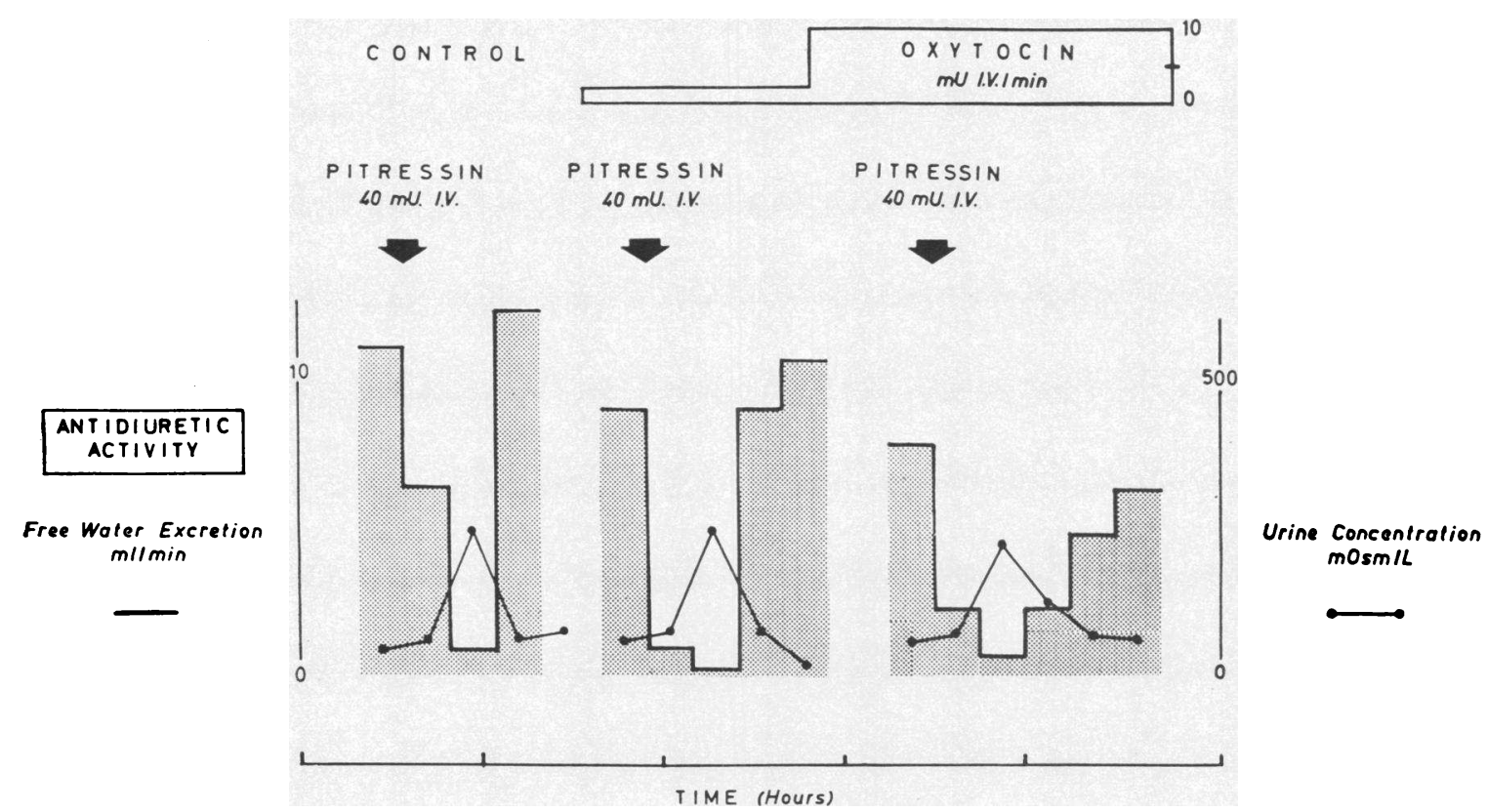

Fig. 1. Lack of Peripheral interaction of oxytocin and vasopressin in man. Pitressin (40 mU, iv) was first given in the absence of oxytocin and then during a continuous infusion of oxytocin ( 2 to $10 \mathrm{mU}$ per minute, iv).

ferent units, the percentile transformation was em- characterize the physiological responses to graded ployed (11).

\section{Results}

A. Studies on the possible interaction of exogenous oxytocin and vasopressin

Before an investigation of the release of endogenous neurohypophyseal hormones, we had to doses of vasopressin and oxytocin and determine whether, when administered separately, the two hormones were clearly different in their effects. We also had to determine whether the two agents, when administered together, might act either as synergists or as mutual antagonists.

Oxytocin in intravenous doses as small as 0.1

\section{CONTROL}

PITRESSIN $40 \mathrm{mU} /$ I.V.min
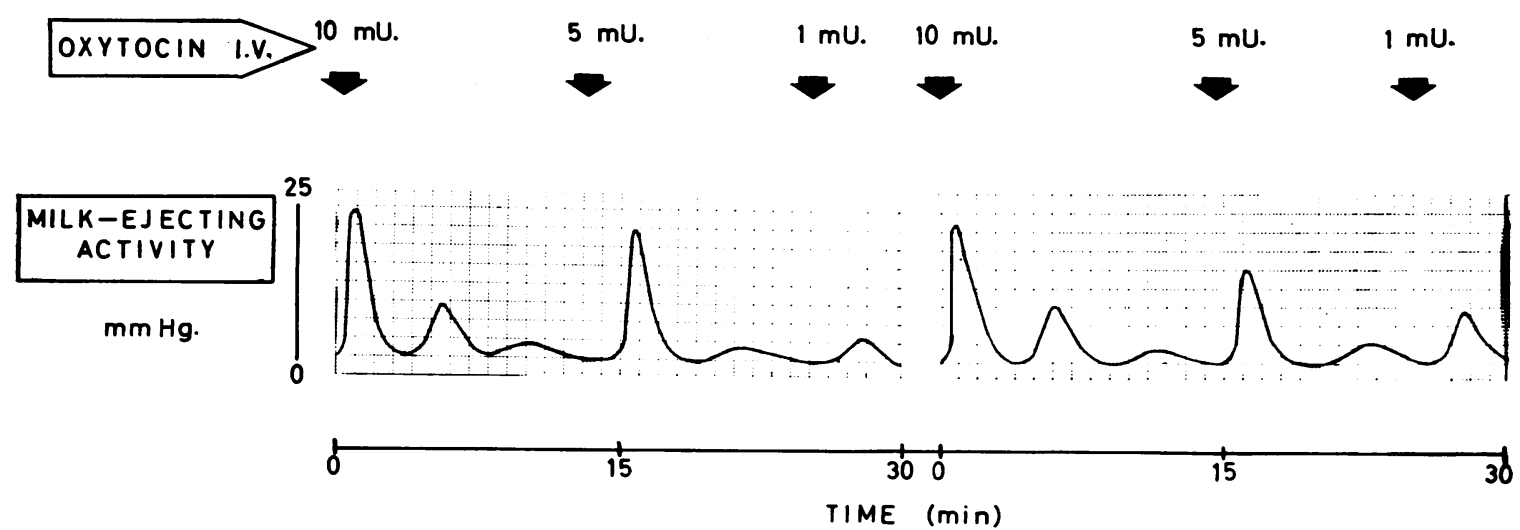

Fig. 2. Lack of Peripheral interaction of vasopressin and oxytocin in man. Oxytocin (1, 5, and $10 \mathrm{mU}$, iv) was first given in the absence of Pitressin and then during a constant infusion of Pitressin ( $40 \mathrm{mU}$, per minute, iv). 


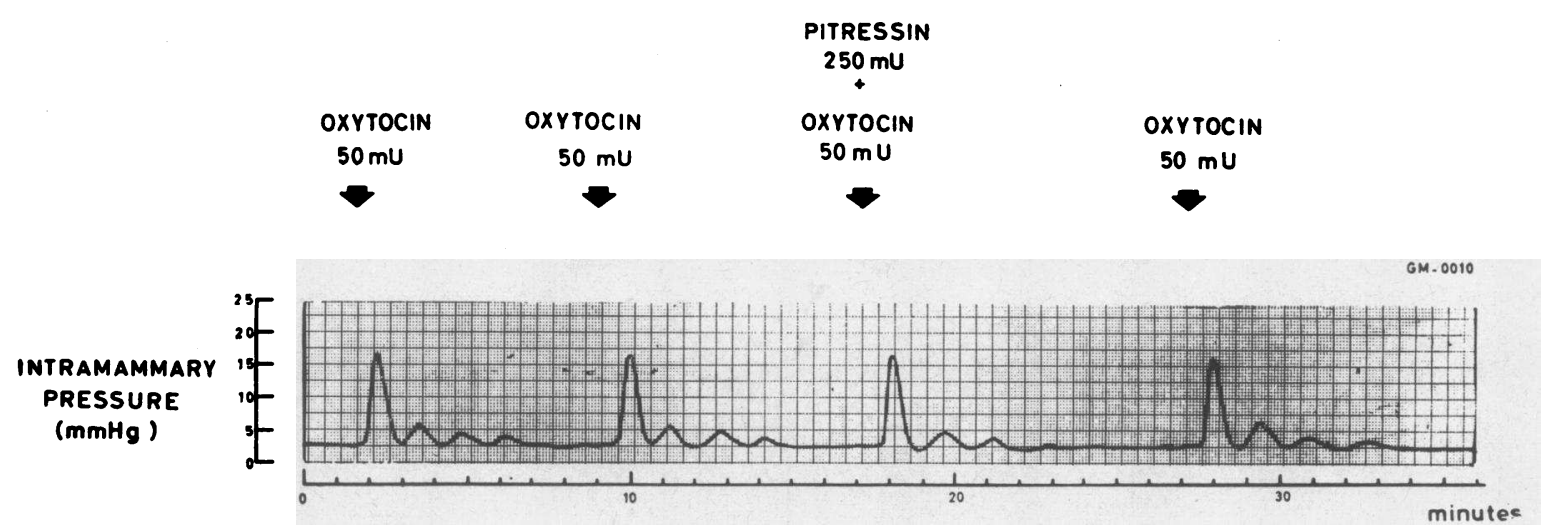

Fig. 3. LACK OF PERIPHERAL interaction OF VASOPRESSin AND OXYTocin IN MAN. Oxytocin (50 mU, iv) was given alone before and after it was given combined with Pitressin (250 $\mathrm{mU}$, iv).

to $2.0 \mathrm{mU}$ caused increased intramammary pressure in all subjects during puerperium, whereas doses of 50 to $100 \mathrm{mU}$ caused significant increases in intrauterine pressure in all subjects during late pregnancy. In contrast, doses up to $500 \mathrm{mU}$ had no antidiuretic effect.

Vasopressin given intravenously twenty times

TABLE I

Lack of effect of Pitressin, nicotine, and 3\% saline on the uterine response to oxytocin

$\overline{\substack{\text { Uterine response } \\ \Delta \text { Montevideo }_{\mathrm{U}^{*}}}}$

Ch. M., 37, F, pregnancy-week 39

Control

Oxytocin, iv, $50 \mathrm{mU}$

Oxytocin, iv, $100 \mathrm{mU}$

58

Pitressin, iv, $2 \mathrm{mU} / \mathrm{min}$

Oxytocin, iv, $100 m U$

Pitressin, iv, $20 \mathrm{mU} / \mathrm{min}$

Oxytocin, iv, $50 \mathrm{mU}$

Oxytocin, iv, $100 \mathrm{mU}$

65

99

Nicotine, iv, $1.5 \mathrm{mg}$

Oxytocin, iv, $50 \mathrm{mU}$

Oxytocin, iv, $100 \mathrm{mU}$

77

R.D., 28, F, pregnancy-week 39

Control

Oxytocin, iv, $75 m U$

Oxytocin, iv, $75 \mathrm{mU}$

40
36

$3 \%$ Saline, iv, $24 \mathrm{~g}$

Oxytocin, iv, $100 \mathrm{mU}$

61

* Numbers correspond to the difference of the means of two 15-minute periods before and after oxytocin administration. to nine subjects during puerperium and seven subjects during late pregnancy, in doses as small as 15 to $20 \mathrm{mU}$, caused a significant increase in urinary osmolality of 162 ( $\mathrm{SE}$ of the mean \pm 35 ) mOsm per $\mathrm{kg}(\mathrm{p}<0.001)$ and a significant decrease in $\mathrm{C}_{\mathrm{H}_{2} \mathrm{O}}$ of 6.2 ( $\mathrm{SE}$ of the mean \pm 0.77 ) $\mathrm{ml}$ per minute $(\mathrm{p}<0.001)$. Such small doses had no appreciable effect upon intramammary or intrauterine pressures. In much larger doses $(100 \mathrm{mU})$, Pitressin was approximately as effective as $1 \mathrm{mU}$ of oxytocin in its effect upon intramammary pressure. Repeated injections of 40 to $80 \mathrm{mU}$ or a constant infusion of 2 to $20 \mathrm{mU}$ per minute of Pitressin did not modify intrauterine pressure.

It appears, therefore, that the physiological effects of oxytocin and vasopressin are clearly distinguishable from each other.

The question of whether oxytocin might inhibit or potentiate the antidiuretic action of vasopressin was examined in two experiments, one during late pregnancy and the other during puerperium. The latter is illustrated by Figure 1 . Vasopressin was found in both situations to have the same effect on water excretion during the infusion of oxytocin as it did in its absence.

In studies designed to determine whether vasopressin might modify the effect of oxytocin on intramammary pressure, oxytocin was found to have the same effect in the presence as it did in the absence of vasopressin, as shown by the experiments illustrated in Figures 2 and 3. Similar results were obtained in studies of the uterine action of oxytocin (Table I).

We also had to determine whether the ex- 
TABLE II

Lack of effect of nicotine and of $3 \%$ saline on the milk-ejecting response to oxytocin

\begin{tabular}{|c|c|c|c|c|c|}
\hline A.B., 23, F Puerperium, day 3 & Oxytocin* dose, iv & Latency & Duration & Pressure & Area \\
\hline & $m U$ & $\min$ & $\min$ & $m m \mathrm{Hg}$ & sq. incht \\
\hline \multirow[t]{8}{*}{$11: 00$ a.m. Control (water diuresis) } & 0.5 & 0.5 & 1.3 & 4 & 0.06 \\
\hline & 1 & 0.4 & 1.6 & 9 & 0.15 \\
\hline & 2 & 0.3 & 1.6 & 11 & 0.19 \\
\hline & 4 & 0.25 & 2.3 & 13 & 0.26 \\
\hline & 6 & 0.15 & 3.0 & 15 & 0.31 \\
\hline & 10 & 0.15 & 3.3 & 17 & 0.38 \\
\hline & 20 & 0.1 & 4.4 & 30 & 0.63 \\
\hline & 40 & 0.05 & 6.2 & 37 & 1.07 \\
\hline \multirow[t]{6}{*}{$2: 15$ p.m. Nicotine, iv, $1 m g$} & 1 & 0.6 & 2.0 & 4 & 0.11 \\
\hline & 2 & 0.5 & 1.7 & 10 & 0.19 \\
\hline & 5 & 0.4 & 2.8 & 16 & 0.33 \\
\hline & 10 & 0.4 & 3.4 & 21 & 0.48 \\
\hline & 20 & 0.2 & 4.2 & 28 & 0.67 \\
\hline & 40 & 0.1 & 6.2 & 36 & 1.21 \\
\hline \multirow[t]{6}{*}{ 5:00 p.m. 3\% Saline, iv, $19 \mathrm{~g}$} & 1 & 0.7 & 1.6 & 3 & 0.08 \\
\hline & 2 & 0.7 & 3.4 & 15 & 0.34 \\
\hline & $\overline{5}$ & 0.35 & 3.4 & 20 & 0.47 \\
\hline & 10 & 0.15 & 4.5 & 23 & 0.70 \\
\hline & 20 & 0.1 & 6.5 & 30 & 0.89 \\
\hline & 40 & 0.05 & 7.7 & 35 & 1.16 \\
\hline
\end{tabular}

* Oxytocin (Syntocinon) was given in successive single injections during water diuresis (control) and during antidiuresis to nicotine and $3 \%$ saline.

$\dagger$ One sq. inch corresponds to $15 \mathrm{~mm} \mathrm{Hg} \times 2.5$ minutes.

perimental manipulations to be used to evoke secretion of either vasopressin or oxytocin would modify the physiologic response to the alternate hormone. By using intramammary pressure recordings, dose-response curves were established for oxytocin during water diuresis, during nicotine-induced antidiuresis, and during hypertonic saline-induced antidiuresis. These maneuvers had no appreciable effect on the mammary response to oxytocin (Table II). Similarly, the uterine response to oxytocin was unaltered by nicotine or hypertonic saline (Table I). Conversely, the antidiuretic responses to vasopressin were unaltered by suckling (Table III).

On the basis of these preliminary studies, we concluded that, if vasopressin and oxytocin are actually secreted separately by the human neurohypophysis, we should be able to demonstrate this fact, using as indexes of hormonal activity changes in intramammary or intrauterine pressure, on the one hand, or changes in water diuresis, on the other.

TABLE III

Lack of effect of suckling on the antidiuretic response to Pitressin

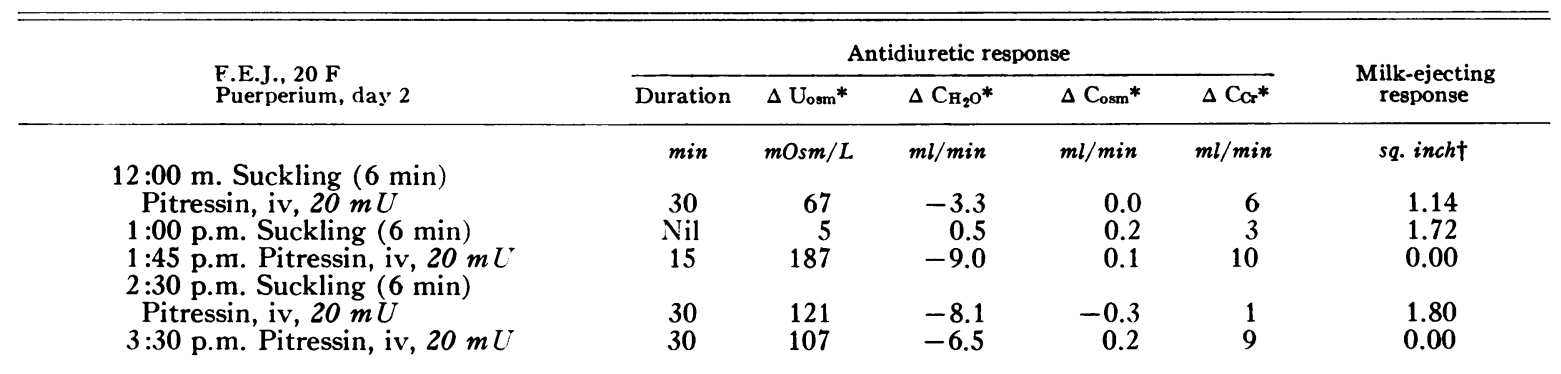

* All values represent the difference of individual values ( $\mathrm{U}_{\mathrm{osm}}, \mathrm{C}_{\mathrm{H}_{2} \mathrm{O}}$ ) or the means of 2 to 415 -minute clearance periods before and after suckling or Pitressin, or both. $\mathrm{U}_{\mathrm{osm}}=$ urine osmolality; $\mathrm{C}_{\mathrm{H}_{2} \mathrm{O}}=\mathrm{free}_{\mathrm{water}}$ clearance; $\mathrm{C}_{\mathrm{osm}}$ $=$ solute clearance $\mathrm{C}_{\mathbf{C r}}=$ creatinine clearance.

$\dagger$ One sq. inch corresponds to $15 \mathrm{~mm} \mathrm{Hg} \times 2.5$ minutes. 


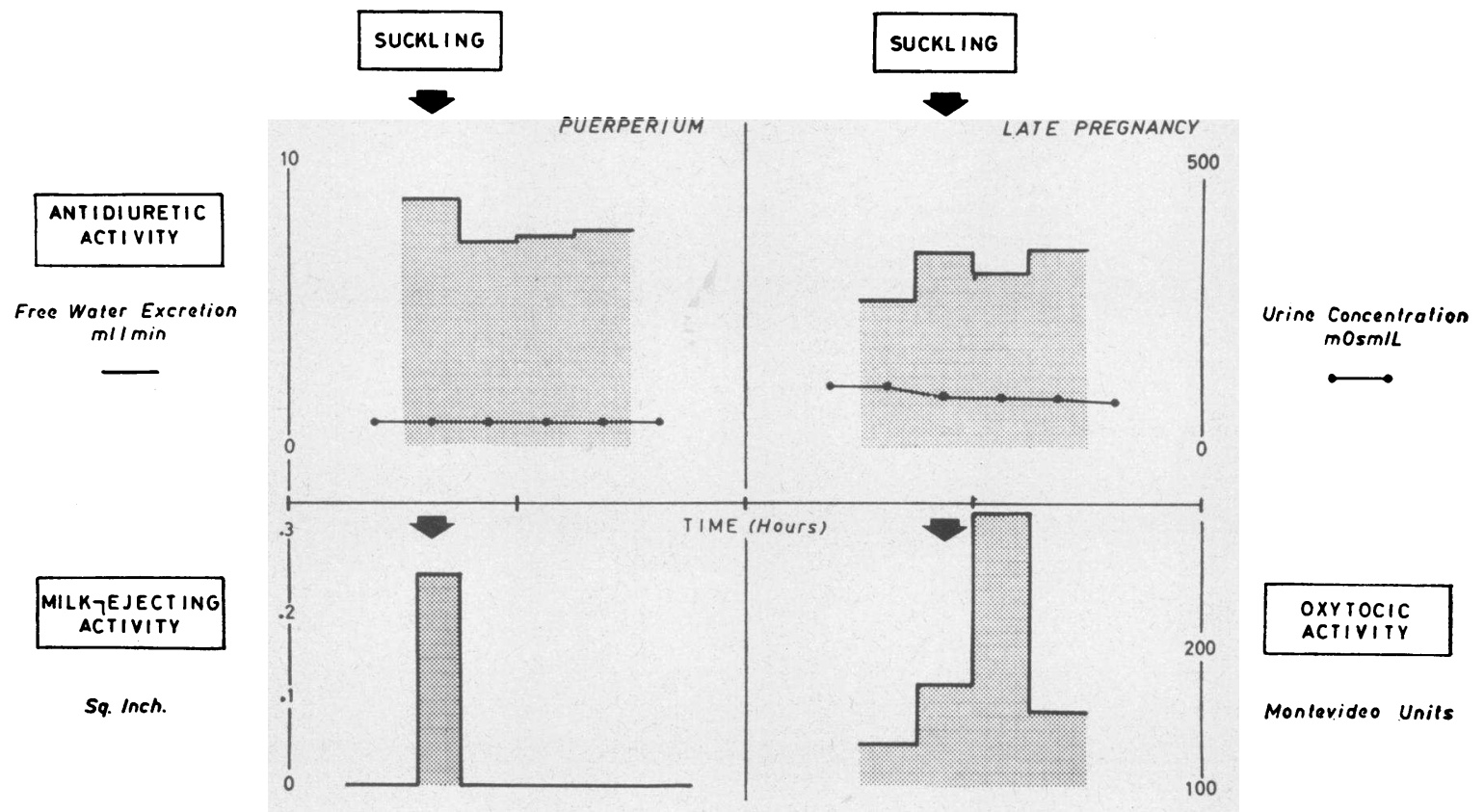

Fig. 4. EFFECT OF SUCKLING ON INDEXES OF NEUROHYPOPHYSEAL SECRETION.

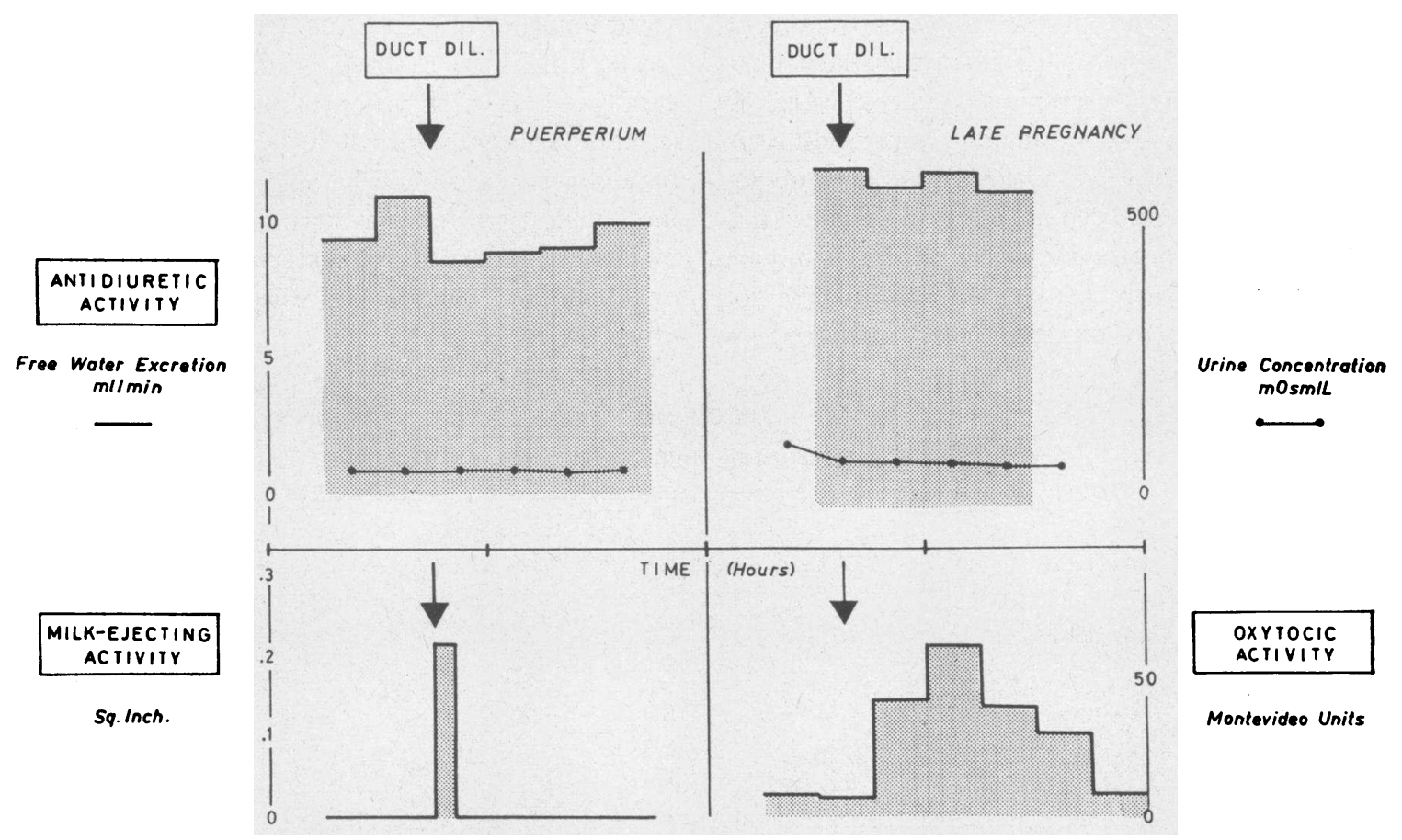

Fig. 5. EFFECT OF MAMMARY DUCT Dilatation ON INDEXeS OF NEUROH YPOPHYSEAL SECRETION. 


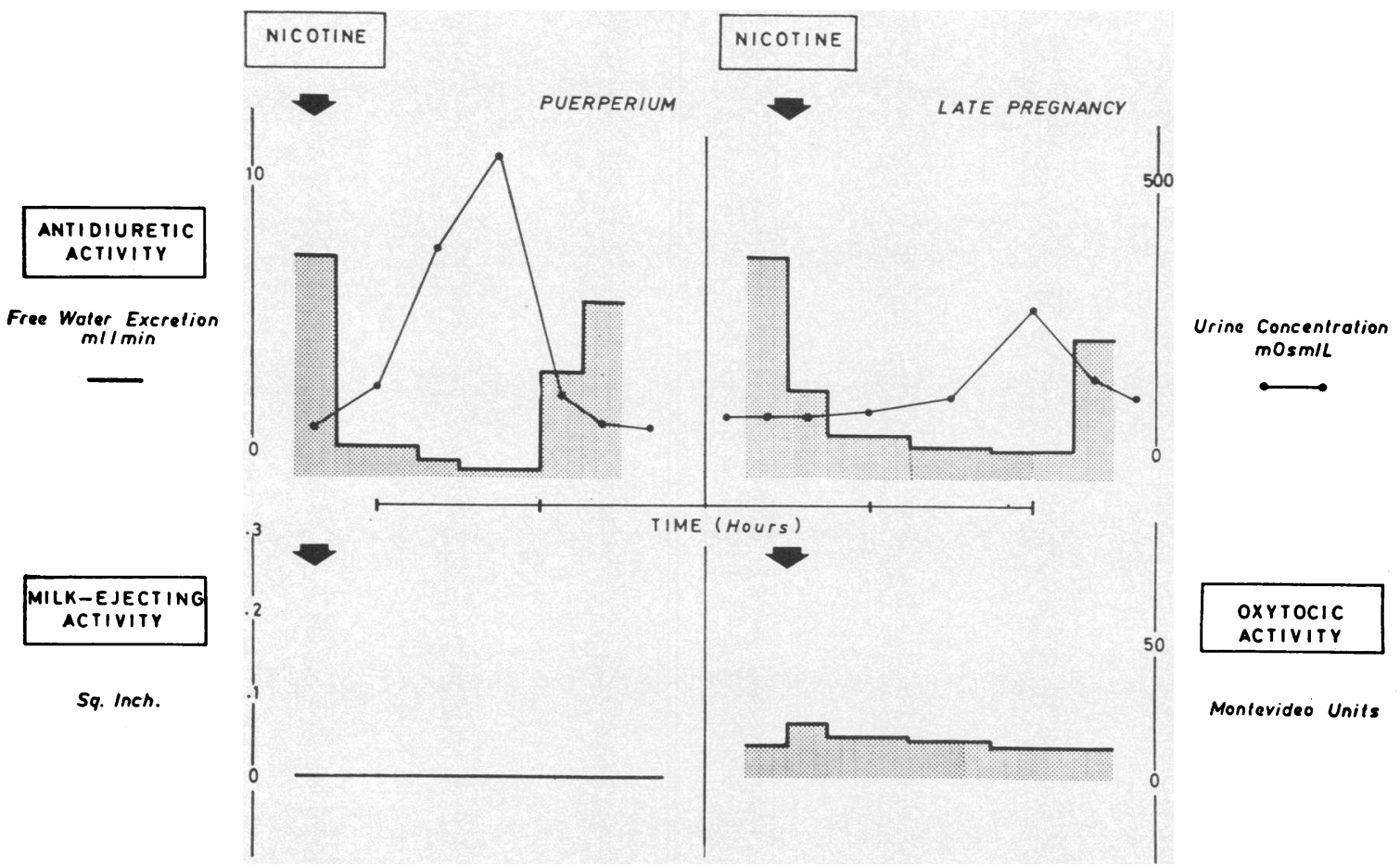

Fig. 6. EFFECT OF NICOTINE ON INDEXES OF NEUROHYPOPHYSEAL SECRETION.

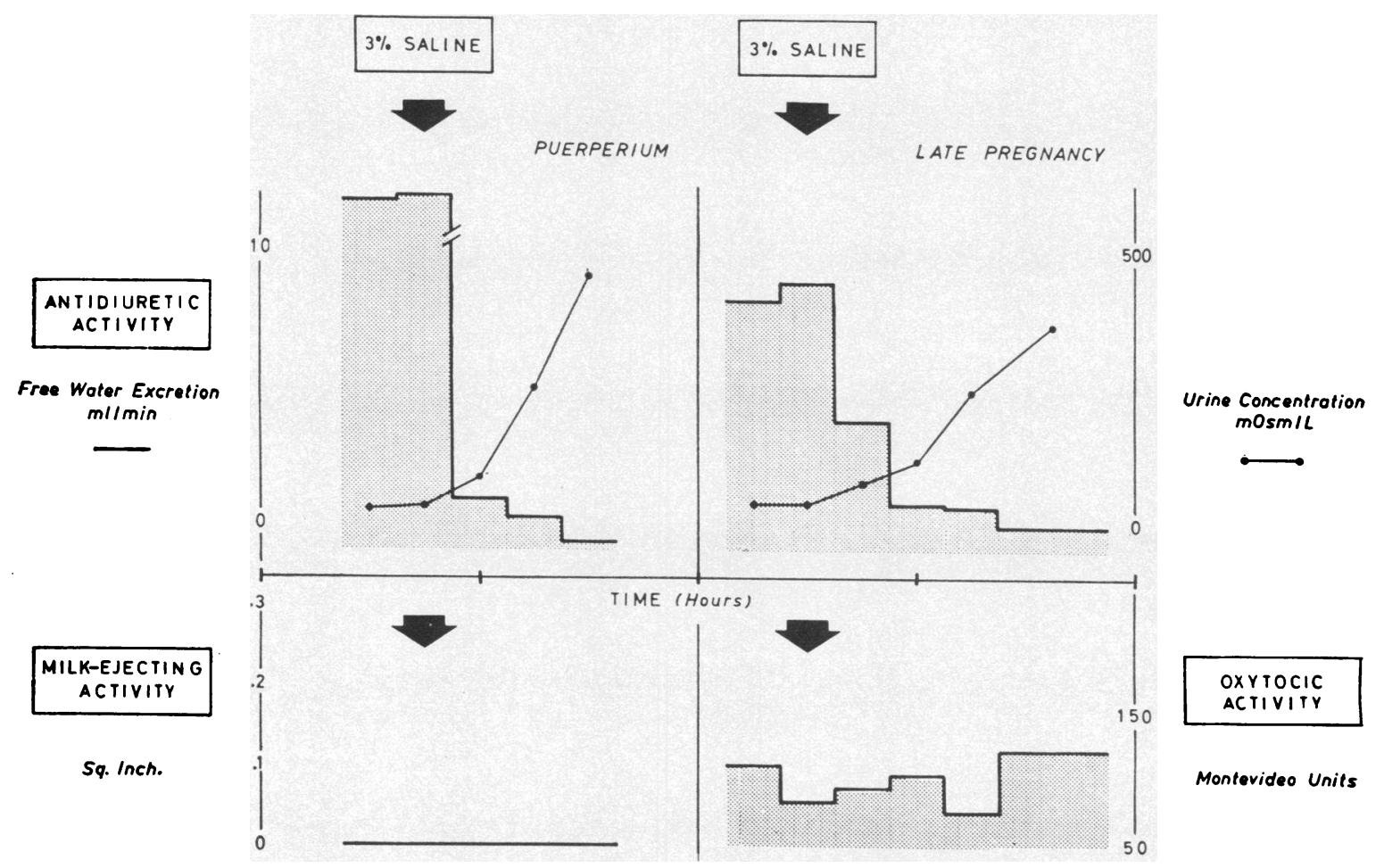

Fig. 7. EFFECT OF HYPERTONICITY ON INDEXES OF NEUROHYPOPHYSEAL SECRETION. 


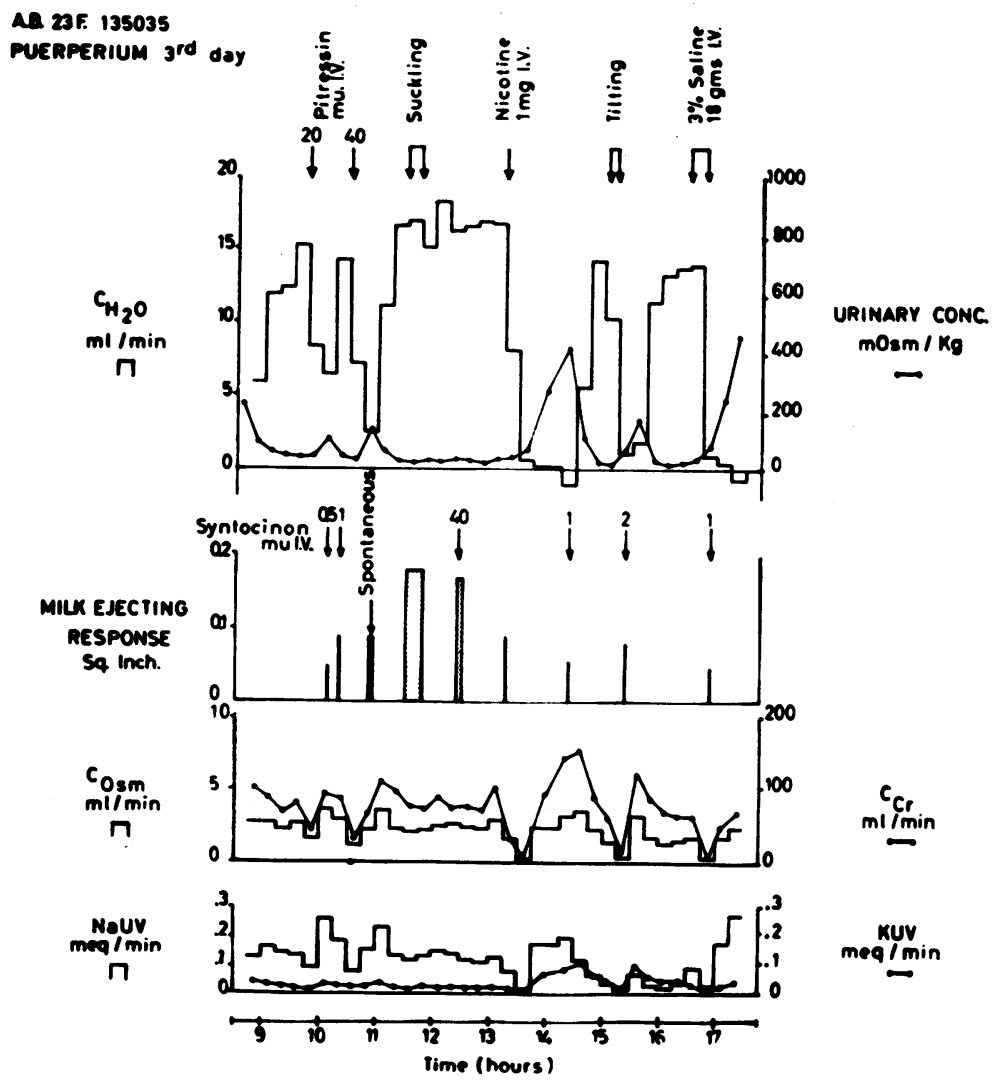

Fig. 8. Procedures AND PARAMETERS EMPloyed to DETERMINE THE RELEASE OF NEUROHYPOPHYSEAL HORMONES IN MAN. $\mathrm{C}_{\mathrm{H}_{2} \mathrm{O}}=$ free water clearance; $\mathrm{C}_{\mathrm{osm}}=$ solute clearance; $\mathrm{NaUV}=$ rate of sodium excretion; $\mathrm{C}_{\mathbf{C r}}$ $=$ creatinine clearance ; $\mathrm{KUV}=$ rate of potassium excretion.

B. Studies of endogenous neurohypophyseal hormone secretion

In each experiment the sensitivities of the kidney, mammary gland, and uterus to standard injections of vasopressin and to oxytocin were determined.

1) Physiologic stimulation of oxytocin secretion. As a physiologic stimulus to oxytocin secretion, suckling of one mammary gland was employed, 24 times in 19 subjects. The baby was allowed to suck for approximately 10 minutes. The other mammary gland was used for pressure recordings. In response to suckling there was, in puerperal women, a reproducible and marked increase in intrammary pressure, but there was no concomitant antidiuresis. During late pregnancy there was a marked increase in uterine activity, but there was no concomitant antidiuresis (Figure 4). These mammary and uterine responses corresponded to the effect of approximately $100 \mathrm{mU}$ of oxytocin, as directly tested on these patients. The lack of antidiuretic response was consistent with the view that less than $15 \mathrm{mU}$ of antidiuretic hormone was secreted in response to suckling.

As another stimulus to oxytocin secretion, dilatation of a mammary duct in the gland opposite to that used for recording was employed. Duct dilatation was used 11 times in nine subjects. In response to duct dilatation during the puerperium there was a reproducible and marked increase in intramammary pressure, but there was no concomitant antidiuresis. During late pregnancy there was a marked increase in uterine activity but no concomitant antidiuresis (Figure 5).

We conclude that suckling and mammary duct 
TABLE IV

Effect of suckling, mammary duct dilatation, nicotine, and $3 \%$ saline on the neurohypophyseal release of oxytocin and vasopressin in man

\begin{tabular}{|c|c|c|c|c|c|c|c|c|c|c|c|}
\hline \multirow[b]{2}{*}{ Subject } & \multicolumn{8}{|c|}{ Antidiuretic response } & \multicolumn{3}{|c|}{$\begin{array}{l}\text { Milk-ejecting and uterine } \\
\text { response* }\end{array}$} \\
\hline & \multicolumn{2}{|c|}{$\begin{array}{c}\text { Urine } \\
\text { concentration }\end{array}$} & \multicolumn{2}{|c|}{$\mathrm{C}_{\mathrm{H}_{2} \mathrm{O}}$} & \multicolumn{2}{|c|}{$\mathrm{C}_{\text {osm }}$ (mean) } & \multicolumn{2}{|c|}{$\underset{\mathrm{C}_{\mathrm{Cr}} \text { (mean) }}{\mathrm{GFRt}}$} & $\begin{array}{c}\text { Puer- } \\
\text { perium }\end{array}$ & $\begin{array}{l}\text { Preg- } \\
\text { nancy }\end{array}$ & $\begin{array}{l}\text { Percentile } \\
\text { value }\end{array}$ \\
\hline & \multicolumn{2}{|c|}{$\mathrm{mOsm} / \mathrm{kg}$} & \multicolumn{2}{|c|}{$\mathrm{ml} / \mathrm{min}$} & \multicolumn{2}{|c|}{$m l / m i n$} & \multicolumn{2}{|c|}{$m l / \min$} & \multirow{2}{*}{$\begin{array}{l}\text { sq. } \\
\text { inch }\end{array}$} & \multirow{2}{*}{$\begin{array}{l}\text { Monte- } \\
\text { video } U\end{array}$} & \\
\hline & Control+ & Expl. 8 & Control & Expl. & $\begin{array}{l}\text { Control } \\
\text { Suckling }\end{array}$ & Exp. & Control & Exp. & & & \\
\hline $\begin{array}{l}\text { 1. F.E.J. } \\
\text { 2. E.R. } \\
\text { 3. L.A. } \\
\text { 4. S.L. } \\
\text { 5. R.D. } \\
\text { 6. S.M. } \\
\text { 7. A.B. } \\
\text { 8. C.A. } \\
\text { 9. C.M.D. } \\
\text { 10. S.D. } \\
\text { 11. M.A. } \\
\text { 12. J.H. } \\
\text { 13. L.A. } \\
\text { 14. U.M. } \\
\text { 15. S.M.E. } \\
\text { 16. Y.G. } \\
\text { 17. C.L. } \\
\text { 18. F.R. } \\
\text { 19. C.Y. }\end{array}$ & $\begin{array}{r}60 \\
92 \\
91 \\
41 \\
82 \\
106 \\
33 \\
190 \\
76 \\
154 \\
120 \\
72 \\
295 \\
40 \\
101 \\
87 \\
53 \\
45 \\
125 \\
91 \\
141 \\
254 \\
25 \\
32\end{array}$ & $\begin{array}{r}60 \\
35 \\
165 \\
44 \\
107 \\
113 \\
33 \\
209 \\
63 \\
172 \\
111 \\
105 \\
175 \\
75 \\
115 \\
110 \\
52 \\
80 \\
88 \\
87 \\
145 \\
161 \\
37 \\
55\end{array}$ & $\begin{array}{r}7.6 \\
10.3 \\
3.2 \\
9.7 \\
3.5 \\
11.2 \\
16.8 \\
1.1 \\
7.8 \\
3.2 \\
3.6 \\
5.5 \\
0.0 \\
11.2 \\
7.2 \\
7.8 \\
14.1 \\
12.4 \\
9.0 \\
6.9 \\
1.5 \\
0.6 \\
15.5 \\
21.8\end{array}$ & $\begin{array}{r}8.6 \\
12.2 \\
1.3 \\
7.5 \\
2.3 \\
5.1 \\
18.3 \\
0.8 \\
10.9 \\
2.8 \\
5.1 \\
3.8 \\
1.7 \\
5.9 \\
5.6 \\
6.4 \\
10.9 \\
8.6 \\
9.5 \\
7.0 \\
0.4 \\
1.0 \\
13.7 \\
16.1\end{array}$ & $\begin{array}{l}1.9 \\
3.6 \\
1.6 \\
1.7 \\
1.6 \\
5.1 \\
2.3 \\
2.2 \\
2.9 \\
2.1 \\
3.3 \\
2.3 \\
1.5 \\
2.0 \\
4.1 \\
3.8 \\
3.1 \\
2.4 \\
3.5 \\
2.8 \\
0.8 \\
1.9 \\
1.7 \\
4.1\end{array}$ & $\begin{array}{l}2.2 \\
2.0 \\
1.5 \\
1.5 \\
1.5 \\
4.2 \\
2.3 \\
1.9 \\
2.3 \\
2.2 \\
3.1 \\
2.1 \\
1.8 \\
2.0 \\
3.8 \\
3.9 \\
2.4 \\
2.4 \\
3.7 \\
2.9 \\
0.5 \\
1.5 \\
2.0 \\
3.1\end{array}$ & $\begin{array}{r}57 \\
85 \\
82 \\
38 \\
78 \\
53 \\
79 \\
86 \\
55 \\
64 \\
51 \\
66 \\
54 \\
80 \\
49 \\
53 \\
110 \\
94 \\
80 \\
110 \\
29 \\
47 \\
102 \\
166\end{array}$ & $\begin{array}{r}60 \\
63 \\
76 \\
42 \\
74 \\
53 \\
80 \\
81 \\
46 \\
75 \\
80 \\
57 \\
69 \\
79 \\
50 \\
50 \\
91 \\
85 \\
57 \\
87 \\
22 \\
45 \\
106 \\
141\end{array}$ & $\begin{array}{l}1.72 \| \\
2.74 \\
2.42 \\
3.00 \\
2.10 \\
5.44 \\
3.28 \\
1.12 \\
1.18 \\
1.33 \\
2.70 \\
2.11 \\
1.42 \\
1.46 \\
3.14 \\
3.04 \\
1.36 \\
1.35 \\
4.88\end{array}$ & $\begin{array}{r}137 \\
46 \\
30 \\
88 \\
172\end{array}$ & $\begin{array}{r}25.3 \\
40.4 \\
35.4 \\
43.4 \\
30.3 \\
79.8 \\
47.5 \\
16.2 \\
17.2 \\
19.2 \\
39.4 \\
31.3 \\
21.2 \\
21.2 \\
46.5 \\
44.4 \\
20.2 \\
20.2 \\
71.7 \\
79.8 \\
27.3 \\
17.2 \\
51.5 \\
101.0\end{array}$ \\
\hline $\begin{array}{r}\text { Mean } \\
\text { SD }\end{array}$ & $\begin{array}{c}100.3 \\
71.0 \\
p>\end{array}$ & $\begin{array}{r}99.9 \\
54.2 \\
90\end{array}$ & $\begin{array}{l}7.98 \\
5.81 \\
p>\end{array}$ & $\begin{array}{r}6.90 \\
5.15 \\
.80\end{array}$ & $\begin{array}{c}2.60 \\
1.16 \\
p>\end{array}$ & $\begin{array}{l}2.37 \\
1.01 \\
.80\end{array}$ & $\begin{array}{c}73.7 \\
33.2 \\
\text { p }>\end{array}$ & $\begin{array}{l}69.5 \\
28.4 \\
.80\end{array}$ & & & $\begin{array}{l}39.5 \\
24.5 \\
\mathrm{p}<.001\end{array}$ \\
\hline & & & & Mamm & duct di & latatic & & & & & \\
\hline $\begin{array}{l}\text { 1. S.L. } \\
\text { 2. L.A. } \\
\text { 3. S.M. } \\
\text { 4. J.H. } \\
\text { 5. L.A. } \\
\text { 6. R.D. } \\
\text { 7. A.B. } \\
\text { 8. G.D. } \\
\text { 9. Y.G. }\end{array}$ & $\begin{array}{r}41 \\
122 \\
80 \\
70 \\
75 \\
87 \\
255 \\
52 \\
40 \\
90 \\
39\end{array}$ & $\begin{array}{r}46 \\
120 \\
101 \\
77 \\
80 \\
110 \\
253 \\
47 \\
35 \\
69 \\
51\end{array}$ & $\begin{array}{r}9.3 \\
7.4 \\
11.1 \\
6.6 \\
5.9 \\
4.2 \\
0.3 \\
11.6 \\
9.4 \\
3.4 \\
7.1\end{array}$ & $\begin{array}{r}8.7 \\
7.1 \\
10.4 \\
7.3 \\
5.5 \\
2.0 \\
0.1 \\
11.5 \\
10.1 \\
4.1 \\
8.2\end{array}$ & $\begin{array}{l}1.8 \\
5.5 \\
4.3 \\
2.3 \\
2.0 \\
2.0 \\
1.7 \\
2.3 \\
1.7 \\
3.5 \\
1.5\end{array}$ & $\begin{array}{l}1.7 \\
4.6 \\
5.7 \\
2.0 \\
2.1 \\
1.6 \\
1.7 \\
2.3 \\
1.5 \\
4.5 \\
1.6\end{array}$ & $\begin{array}{l}43 \\
55 \\
95 \\
79 \\
81 \\
97 \\
86 \\
87 \\
76 \\
59 \\
40\end{array}$ & $\begin{array}{l}39 \\
53 \\
66 \\
73 \\
76 \\
83 \\
77 \\
80 \\
73 \\
46 \\
69\end{array}$ & $\begin{array}{l}0.83 \\
4.38 \\
6.91 \\
2.27 \\
1.25 \\
0.49\end{array}$ & $\begin{array}{r}134 \\
41 \\
60 \\
50 \\
50\end{array}$ & $\begin{array}{r}12.1 \\
63.6 \\
101.0 \\
33.3 \\
18.2 \\
7.1 \\
78.8 \\
24.2 \\
35.4 \\
29.3 \\
29.3\end{array}$ \\
\hline $\begin{array}{r}\text { Mean } \\
\text { SD }\end{array}$ & $\begin{array}{c}86.5 \\
67.2 \\
p>\end{array}$ & $\begin{array}{r}89.9 \\
67.2 \\
90\end{array}$ & $\begin{array}{c}6.93 \\
4.06 \\
p>\end{array}$ & $\begin{array}{l}6.82 \\
4.18 \\
.90\end{array}$ & $\begin{array}{c}2.60 \\
1.53 \\
p>\end{array}$ & $\begin{array}{l}2.66 \\
1.73 \\
.90\end{array}$ & $\begin{array}{c}72.5 \\
30.6 \\
p>\end{array}$ & $\begin{array}{l}66.8 \\
25.0 \\
.60\end{array}$ & & & $\begin{array}{l}39.3 \\
31.9 \\
\mathrm{p}<.005\end{array}$ \\
\hline
\end{tabular}

* Milk-ejecting activity after stimulations is represented by the increment in square inches from a control value of zero. Uterine activity is represented in Montevideo units by the difference of the means of three to eight 15-minute periods before and after stimulations.

$\dagger \mathrm{GFR}=$ glomerular filtration rate.

$\ddagger$ Control refers to individual values $\left(\mathrm{U}_{\mathrm{osm}}, \mathrm{C}_{\mathrm{H}_{2} \mathrm{O}}\right.$ ) or the mean of four (2 to 13) 15-minute clearance periods ( $\mathrm{C}_{\mathrm{osm}}$, $\mathrm{C}_{\mathbf{C}}$ ) before stimulations.

$\$$ Exp. refers to individual values ( $\mathrm{U}_{\text {osm }}, \mathrm{C}_{\mathrm{H}_{2} \mathrm{O}}$ ) or the mean of four (2 to 11) 15-minute clearance periods ( $\mathrm{C}_{\mathrm{osm}}$, $\mathrm{C}_{\mathrm{Cr}}$ ) after stimulations.

\| One square inch corresponds to $15 \mathrm{~mm} \mathrm{Hg}$ per 2.5 minutes. 
TABLE IV-(Continued $)$

\begin{tabular}{|c|c|c|c|c|c|c|c|c|c|c|c|}
\hline \multirow[b]{2}{*}{ Subject } & \multicolumn{8}{|c|}{ Antidiuretic response } & \multicolumn{3}{|c|}{$\begin{array}{l}\text { Milk-ejecting and uterine } \\
\text { response* }\end{array}$} \\
\hline & \multicolumn{2}{|c|}{$\begin{array}{c}\text { Urine } \\
\text { concentration }\end{array}$} & \multicolumn{2}{|c|}{$\mathrm{C}_{\mathrm{H}_{2} \mathrm{O}}$} & \multicolumn{2}{|c|}{ Cosm (mean) } & \multicolumn{2}{|c|}{$\begin{array}{c}\mathrm{GFR} \dagger \\
\mathrm{C}_{\mathrm{Cr}}(\text { mean })\end{array}$} & $\begin{array}{c}\text { Puer- } \\
\text { perium }\end{array}$ & $\begin{array}{l}\text { Preg- } \\
\text { nancy }\end{array}$ & $\begin{array}{c}\text { Percentile } \\
\text { value }\end{array}$ \\
\hline & \multicolumn{2}{|c|}{$m O s m / K g$} & \multicolumn{2}{|c|}{$m l / \min$} & \multicolumn{2}{|c|}{$m l / m i n$} & \multicolumn{2}{|c|}{$\mathrm{ml} / \mathrm{min}$} & \multirow{3}{*}{$\begin{array}{l}\text { sq. } \\
\text { inch }\end{array}$} & \multirow[t]{3}{*}{$\begin{array}{l}\text { Monte- } \\
\text { video } U\end{array}$} & \\
\hline & Control & Exp. $\S$ & Control & Expl. & Control & Exp. & Control & Exp. & & & \\
\hline \multicolumn{10}{|c|}{ Nicotine } & & \\
\hline 1. L.M.E. & 80 & 607 & 3.4 & -0.6 & 1.3 & 0.7 & 55 & 60 & 0.71 & & 10.1 \\
\hline 2. C.A. & 182 & 415 & 1.0 & -0.5 & 1.6 & 1.6 & 72 & 65 & 0.24 & & 4.0 \\
\hline 3. S.M.E. & 69 & 152 & 10.4 & 1.4 & 3.3 & 3.0 & 52 & 56 & 0.00 & & 0.0 \\
\hline 4. L.A. & 92 & 312 & 4.3 & -0.1 & 2.3 & 1.9 & 113 & 105 & 0.27 & & 4.0 \\
\hline 5. S.L. & 37 & 542 & 9.1 & -0.6 & 1.5 & 0.9 & 43 & 40 & 0.00 & & 0.0 \\
\hline 6. A.B. & 41 & 432 & 16.8 & -1.1 & 2.5 & 2.2 & 85 & 89 & 0.16 & & 2.0 \\
\hline & 33 & 448 & 11.1 & -1.1 & 1.6 & 1.5 & 79 & 77 & & 5 & 3.0 \\
\hline 7. G.D. & 48 & 488 & 10.8 & -0.7 & 2.0 & 1.3 & 48 & 48 & 0.00 & & 0.0 \\
\hline & 39 & 409 & 7.7 & -0.8 & 1.4 & 1.6 & 60 & 51 & & -15 & -9.1 \\
\hline 8. D.I. & 43 & 325 & 10.7 & -0.6 & 1.5 & 1.7 & 82 & 87 & & 11 & 7.1 \\
\hline 9. R.D. & 66 & 259 & 7.2 & 0.3 & 1.7 & 1.5 & 71 & 55 & & 5 & 3.0 \\
\hline \multirow[t]{2}{*}{$\begin{array}{r}\text { Mean } \\
\text { SD }\end{array}$} & $\begin{array}{l}66.4 \\
47.8\end{array}$ & $\begin{array}{l}399.0 \\
181.2\end{array}$ & $\begin{array}{l}8.41 \\
5.12\end{array}$ & $\begin{array}{c}-0.4 \\
0.72\end{array}$ & $\begin{array}{r}1.88 \\
.85\end{array}$ & $\begin{array}{r}1.63 \\
.80\end{array}$ & $\begin{array}{l}69.1 \\
29.9\end{array}$ & $\begin{array}{l}66.6 \\
29.3\end{array}$ & & & $\begin{array}{l}2.2 \\
4.9\end{array}$ \\
\hline & \multicolumn{2}{|c|}{$\mathrm{p}<.001$} & \multicolumn{2}{|c|}{$\mathrm{p}<.001$} & \multicolumn{2}{|c|}{$\mathrm{p}>.50$} & \multicolumn{2}{|c|}{$\mathrm{p}>.80$} & & & $\mathrm{p}>.15$ \\
\hline \multicolumn{12}{|c|}{$3 \%$ Saline } \\
\hline 1. S.M.E. & 95 & 446 & 9.2 & -0.6 & 3.0 & 3.0 & 56 & 45 & 0.40 & & 6.1 \\
\hline 2. E.R. & 49 & 366 & 6.9 & -1.9 & 1.9 & 5.5 & 64 & 63 & 0.00 & & 0.0 \\
\hline 3. S.M. & 107 & 373 & 2.9 & -0.5 & 1.8 & 1.5 & 54 & 33 & 0.00 & & 0.0 \\
\hline 4. R.D. & 131 & 255 & 1.4 & 0.1 & 1.3 & 0.9 & 76 & 64 & 0.00 & & 0.0 \\
\hline & 128 & 583 & 0.7 & -2.3 & 1.4 & 2.0 & 65 & 111 & & -9 & -5.1 \\
\hline 5. A.B. & 27 & 452 & 13.8 & -0.8 & 1.5 & 1.5 & 74 & 49 & 0.00 & & 0.0 \\
\hline & 35 & 361 & 8.2 & -0.2 & 1.3 & 1.1 & 61 & 37 & & -10 & -6.1 \\
\hline 6. G.D. & 90 & 476 & 3.2 & -1.6 & 1.6 & 2.8 & 51 & 65 & & 10 & 6.1 \\
\hline 7. F.R. & 25 & 310 & 14.6 & -0.4 & 1.8 & 3.0 & 87 & 80 & & -30 & -17.2 \\
\hline Mean & $\begin{array}{l}76.3 \\
50.7\end{array}$ & $\begin{array}{l}402.4 \\
172.8\end{array}$ & $\begin{array}{l}6.77 \\
5.56\end{array}$ & $\begin{array}{r}-0.91 \\
0.83\end{array}$ & $\begin{array}{l}1.73 \\
82\end{array}$ & $\begin{array}{l}2.37 \\
165\end{array}$ & 65.3 & 60.8 & & & -1.8 \\
\hline & $\mathrm{p}<<$ & $001^{2.0}$ & $p<$ & $.002^{-00}$ & $\mathrm{p}>$ & .30 & $p>$ & .70 & & & $p>.45$ \\
\hline
\end{tabular}

dilatation stimulate the release of physiologically significant quantities of oxytocin without release of appreciable quantities of vasopressin.

2) Physiologic stimulation of vasopressin secretion. As a stimulus to vasopressin secretion, nicotine ( $1.0 \mathrm{mg}$, iv) was injected 11 times in nine subjects. Nicotine caused marked antidiuresis both in the puerperium and in late pregnancy, but had no appreciable effect on intramammary pressure or uterine activity (Figure 6). These results corresponded to the effect of approximately $300 \mathrm{mU}$ of Pitressin and to less than $0.2 \mathrm{mU}$ in the puerperium and less than $50 \mathrm{mU}$ of oxytocin in late pregnancy.

As a second stimulus to vasopressin secretion, $3 \%$ saline, $10 \mathrm{ml}$ per $\mathrm{kg}$ of body weight, was infused intravenously for 15 to 30 minutes, 9 times in seven subjects. This amount produced a rise in plasma osmolality of about $3 \%(10 \mathrm{mOsm}$ per $\mathrm{kg}$ ). Hypertonic saline caused marked antidiuresis both in the puerperium and in late pregnancy but had no appreciable effect on intramammary pressure or uterine activity (Figure 7 ).

We conclude that nicotine and hypertonic saline stimulate the release of physiologically significant quantities of vasopressin without release of appreciable quantities of oxytocin.

The performance of a complete experiment is illustrated by Figure 8 .

Table IV summarizes all the observations. The numerical results obtained were analyzed from the point of view of the statistical significance of the changes observed. We found that suckling produced a significant change in oxytocic/milkejecting activity $(\mathrm{p}<0.001)$ without altering antidiuretic activity [urine osmolality $\left(\mathrm{U}_{\mathrm{osm}}\right): \mathrm{p}>$ $0.90 ; \mathrm{C}_{\mathrm{H}_{2} \mathrm{O}}, \mathrm{C}_{\mathrm{osm}}$, and $\left.\mathrm{C}_{\mathrm{Cr}}: \mathrm{p}>0.80\right]$. Mammary duct dilatation induced a significant change in 
oxytocic/milk-ejecting activity $(\mathrm{p}<0.005)$ without altering antidiuretic activity $\left(\mathrm{U}_{\mathrm{osm}}, \mathrm{C}_{\mathrm{H}_{2} \mathrm{O}}\right.$, and $\left.\mathrm{C}_{\text {osm }}: \mathrm{p}>0.90 ; \mathrm{C}_{\mathrm{Cr}}: \mathrm{p}>0.60\right)$. Nicotine elicited a significant change in antidiuretic activity $\left(\mathrm{U}_{\text {osm }}\right.$ and $\mathrm{C}_{\mathrm{H}_{2} \mathrm{O}}: \mathrm{p}<0.001 ; \mathrm{C}_{\text {osm }}: \mathrm{p}>0.50 ; \mathrm{C}_{\mathrm{Cr}_{\mathrm{r}}}: \mathrm{p}>$ $0.80)$ without altering oxytocic/milk-ejecting activity $(\mathrm{p}>0.15)$. Finally, injection of hypertonic saline led to a significant change in antidiuretic activity $\left(\mathrm{U}_{\text {osm }}: \mathrm{p}<0.001 ; \mathrm{C}_{\mathrm{H}_{2} \mathrm{O}}: \mathrm{p}<0.002\right.$; $\left.\mathrm{C}_{\text {osm }}: \mathrm{p}>0.30 ; \mathrm{C}_{\mathrm{Cr}}: \mathrm{p}>0.70\right)$ without altering oxytocic/milk-ejecting activity $(\mathrm{p}>0.45)$.

\section{Discussion}

Insofar as is possible with indirect assays, these studies demonstrate that oxytocin and antidiuretic hormone can be released separately as the result of different stimuli to the neurohypophysis. Suckling and mammary duct dilatation appear to be powerful stimuli to oxytocin release but not to vasopressin release. Nicotine and hypertonic saline appear to be potent stimuli to vasopressin release but not to oxytocin release. These facts strongly suggest that in man oxytocin and vasopressin are released independently and that the pathways to the neurohypophysis or the releasing mechanisms, or both, are different for these two hormones. Evidence presented by La Bella. Beaulieu, and Reiffenstein (12) for the existence of separate vasopressin and oxytocin-containing granules in the beef neurohypophysis supports the above concepts.

There is still further evidence to suggest that multiple mechanisms might be involved in the release of antidiuretic hormone. For example, it has also been demonstrated that in man there can occur a failure to respond to hypertonic saline even though the capacity to release antidiuretic hormone in response to nicotine is preserved (1315). Furthermore, hydrocortisone in physiological amounts can inhibit the action of nicotine on the neurohypophysis but not the action of hypertonicity $(15,16)$.

Bioassay technics for vasopressin and oxytocin are full of pitfalls and, when applied to human plasma, they lack specificity and sensitivity. The present investigation, therefore, has been carried out by various indirect methods. For the particular purpose of studying the release of neurohypophyseal hormones, the subject's own changes in uterine, mammary, and renal activities in response to stimuli known to act on the neurohypophysis seemed to be among the most adequate available experimental approaches.

Since such indirect procedures were used in our studies, some discussion on the specificity of the methods is mandatory. The lack of peripheral interaction between oxytocin and vasopressin in regard to their oxytocic/milk-ejecting and antidiuretic activities was demonstrated. Oxytocin did not inhibit or potentiate the antidiuretic action of vasopressin, and vasopressin did not inhibit or potentiate the oxytocic-milk-ejecting activities of oxytocin. Therefore, if both hormones were simultaneously released in adequate amounts, a full response should have been detected concomitantly in the uterus, mammary gland, and renal tubules.

In the rabbit Cross (17) has shown a sympathetic-adrenal inhibition of the milk-ejecting response to oxytocin. Since nicotine causes sympathetic and adrenal medullary discharge, the question might be raised as to whether in our experiments the lack of milk ejection after nicotine necessarily proved that oxytocin had not been released. It was clearly shown in our subjects, however, that nicotine did not alter the milkejecting response or the uterine response to threshold doses of oxytocin.

There is ample evidence that hypertonicity (18) and nicotine (19) result in vasopressin release, and it is logical to conclude that the antidiuretic responses to those stimuli in our experiments were mediated by vasopressin. The lack of antidiuresis after nicotine and $3 \% \mathrm{NaCl}(13)$ in diabetes insipidus and in vasopressin-resistant subjects is further evidence that the antidiuresis in these studies was mediated by vasopressin. Furthermore, the antidiuresis resulting from neurohypophyseal stimulation can be reproduced in all of its characteristics by exogenous vasopressin.

There is convincing evidence that endogenous oxytocin in mammals mediates milk ejection $(1,2$, 20) and influences uterine contractility $(1,20$, 21). These two actions of oxytocin were used in our studies as indexes of the release of this hormone in response to suckling, a stimulus known to produce oxytocin release from the neurohypophysis (2). In response to suckling and to duct dilatation there were marked increases in both uterine and mammary activities. This sug- 
gests that oxytocin was the mediator of uterine and mammary gland responses in our experiments. Uterine and mammary gland responses after suckling and duct dilatation can be reproduced with exogenous oxytocin. The long period of latency ( 0.8 to 2.0 minutes) for the milk-ejecting and uterine responses after suckling or duct dilatation also suggests that the responses are humorally mediated. No artifacts (tilting, outside pressure, washing of the catheter, patient movements, etc.) could mimic the mammary gland responses to oxytocin or suckling. It has previously been reported that other physiological substances such as acetylcholine, serotonin, histamine, angiotensin, and bradykinin produce an increase in intramammary pressure only if they are present in greatly supraphysiologic amounts (2). These points provide evidence for the specificity of mammary gland responses to oxytocin in the human female. Changes in uterine activity as an indicator of oxytocin release are less specific and more difficult to analyze than are the changes in intramammary pressure. An excellent account of the action of oxytocin on the human uterus has been presented by Caldeyro-Barcia (8).

Methodological differences may explain some of the discrepancies encountered when comparing the present study with those previously reported. Several workers have used changes in urine flow in the hydrated animal as an indication of vasopressin release. It is well known that many factors besides vasopressin may decrease urine volume. Therefore, the concomitant determination of glomerular filtration rate, solute excretion, and free water clearance was performed in the present study to provide assurance that the changes in urine flow had all of the characteristics of a vasopressin effect.

A second important factor to consider is the variety of animal species used in different studies. There are great differences, for example, between the mammary gland responses of the rabbit and those of the human female to injections of oxytocin, Pitressin, and acetylcholine. Women respond to 0.2 to $1.0 \mathrm{mU}$ of oxytocin; Pitressin, $100 \mathrm{mU}$, iv, produces a response equivalent to 1 $\mathrm{mU}$ of oxytocin, but acetylcholine (hydrochloride) in doses of less than $50.0 \mathrm{mg}$, iv, does not produce an increase in mammary pressure. Rabbits respond to $1.0 \mathrm{mU}$ of oxytocin; vasopressin, 5.0
$\mathrm{mU}$, iv, produces a response equivalent to $1.0 \mathrm{mU}$ of oxytocin $(4,22)$, and acetylcholine (hydrochloride), $0.005 \mathrm{mg}$, iv, does produce a definite increase in intramammary pressure equivalent to that obtained with 1 to $2 \mathrm{mU}$ of oxytocin.

With such species differences in the specificity and sensitivity of the mammary gland to oxytocin, it is difficult to make a proper comparison between results obtained in man and the rabbit when milk ejection is used as the criterion for oxytocin release.

A third important consideration is the nature and magnitude of stimuli employed. Our results are in full agreement with those reported by Cross (23) and Pickford (24) in rabbits and dogs, respectively, indicating that after suckling there is more oxytocin than vasopressin released.

Holland, Cross, and Sawyer (22), Andersson (25), and Pickford (24) have reported that the intracarotid administration of hypertonic saline in the rabbit, goat, and dog results in milk ejection. The fact that these workers used the intracarotid route for the administration of hypertonic saline in amounts similar to or higher per unit time than those we infused intravenously could explain why they obtained milk ejection. Undoubtedly, the rise in osmotic pressure of the cerebral blood that they produced in their experiments would have exceeded those occurring under physiological conditions and would have been much higher than the $3 \%$ rise we produced using the intravenous route. Holland and associates (22) had to use solutions of $1.5 \mathrm{M}$ (or $8.8 \%$ ) of $\mathrm{NaCl}$ in amounts of 1 to $3 \mathrm{ml}$ in 1 to 7 seconds to obtain milk ejection consistently in rabbits. Vasopressin must have been secreted with such stimulation to the osmoreceptors. That oxytocin may have been secreted concomitantly under such unphysiological conditions, however, is quite possible, since there is evidence that intracarotid injections of hypertonic saline stimulate areas of the brain other than just a localized osmoreceptor (22). Andersson (25) had to give even higher amounts of hypertonic solution of $\mathrm{NaCl}$ in goats to obtain milk ejection.

We cannot explain, in the light of our experiments, the report that the intravenous administration of hypertonic saline in amounts and concentrations similar to those we used caused concomitant antidiuresis and increase in uterine ac- 
tivity in the $\operatorname{dog}(26)$. Important factors might have been the species difference and the intensity of the osmotic stimuli, since the threshold of the antidiuretic hormone release was lower than that of the oxytocin release. Our results fully agree with the observations of Theobald (27) and Dicker (28), who failed to modify uterine activity in pregnant women by producing changes in plasma osmolality.

Nicotine has been reported to produce the release of both hormones in man (29). Since those experiments were carried out in dehydrated subjects and since direct bioassay technics were employed, a proper comparison with our experiments is difficult to make. Similarly, it has also been reported that nicotine in rats produces an increase in the oxytocic activity in blood (30). The doses employed, however, were hundreds of times higher (on a body weight basis) than those we used.

It may therefore be concluded that, under the ordinary physiologic conditions studied in the present investigation, oxytocin and vasopressin are released independently by the human neurohypophysis.

\section{Summary}

Studies in 29 women during the last weeks of pregnancy or during the first week of puerperium, or both, using their own changes in uterine activity (and intramammary pressure) and in urine osmolality as criteria of oxytocin and vasopressin release, respectively, showed that suckling and mammary duct dilatation result in pronounced oxytocic/milk-ejecting activities and negligible antidiuresis. Nicotine and hypertonic saline result in marked antidiuresis and negligible oxytocic/milk-ejecting activities. These results demonstrate that oxytocic/milk-ejecting and antidiuretic activities can be manifested separately as the result of different stimuli to the neurohypophysis. These facts strongly suggest that oxytocin and vasopressin in man are released independently and that the pathways to the neurohypophysis or the releasing mechanisms, or both, are different for these hormones.

It was also demonstrated that oxytocin and vasopressin do not act synergistically or antagonistically in their oxytocic/milk-ejecting and antidiuretic activities.

\section{References}

1. Harris, G. W. Neural Control of the Pituitary Gland. London, Edward Arnold, 1955.

2. Cross, B. A. Neural control of oxytocin secretion in Oxytocin, R. Caldeyro-Barcia and H. Heller, Eds. Oxford, Pergamon Press, 1961.

3. Van Dyke, H. B., K. Adamsons, and S. L. Engel. The storage and liberation of neurohypophyseal hormones in The Neurohypophysis, H. Heller, Ed. New York, Academic Press, 1957.

4. Sawyer, W. H. Neurohypophyseal hormones. Pharmacol. Rev. 1961, 13, 225.

5. Kleeman, C. R., and R. E. Cutler. The neurohypophysis. Ann. Rev. Physiol. 1963, 25, 385.

6. Bonsnes, R. W., and H. H. Taussky. The colorimetric determination of creatinine by the Jaffe reaction. J. biol. Chem. 1945, 158, 581.

7. Wesson, L. B., Jr., and W. P. Anslow, Jr. Effect of osmotic and mercurial diuresis on simultaneous water diuresis. Amer. J. Physiol. 1952, 170, 225.

8. Caldeyro-Barcia, R. Factors Controlling the Action of the Pregnant Human Uterus, M. Kowlessar, Ed. New York, Josiah Macy, Jr., Foundation, 1961.

9. Caldeyro-Barcia, R., Y. Sica-Blanco, J. J. Poseiro, V. González-Pannizza, C. Méndez-Bauer, C. Fielitz, H. Alvarez, S. V. Pose, and C. H. Hendricks. A quantitative study of the action of synthetic oxytocin on the pregnant human uterus. J. Pharmacol. exp. Ther. 1957, 121, 18.

10. Sica-Blanco, Y., C. Méndez-Bauer, N. Sala, H. M. Cabot, and R. Caldeyro-Barcia. Nuevo método para el estudio de la funcionalidad mamaria en la mujer. Arch. Ginec. Obstet. 1959, 17, 63.

11. Walker, H. M., and J. Lev. Statistical inference. New York, Holt, Rinehart, and Winston, 1953.

12. La Bella, F. S., A. Beaulieu, and R. J. Reiffenstein. Evidence for the existence of separate vasopressin and oxytocin-containing granules in the neurohypophysis. Nature (Lond.) 1962, 193, 173.

13. Dingman, J. F., K. Benirschke, and G. W. Thorn. Studies of neurohypophyseal function in man. Diabetes insipidus and psychogenic polydipsia. Amer. J. Med. 1957, 23, 226.

14. Dingman, J. F., A. G. Jessiman, R. H. Despointes, W. G. Hammond, D. D. Matson, K. Emerson, Jr., and F. D. Moore. Residual neurohypophyseal function in hypophysectomized man. New Engl. J. Med. 1959, 260, 997.

15. Gaitán, E., and J. F. Dingman. Hypothalamicpituitary regulation of water metabolism in man (abstract). Proc. Endocr. Soc. June 1959, no. 114.

16. Dingman, J. F., and R. H. Despointes. Adrenal steroid inhibition of vasopressin release from the neurohypophysis of normal subjects and patients with Addison's disease. J. clin. Invest. 1960, 39, 1851. 
17. Cross, B. A. Sympathetico-adrenal inhibition of the neurohypophysial milk-ejection mechanism. J. Endocr. 1953, 9, 7.

18. Verney, E. B. Absorption and excretion of water. The antidiuretic hormone. Lancet 1946, 2, 739.

19. Burn, J. H., L. H. Truelove, and I. Burn. The antidiuretic action of nicotine and of smoking. Brit. med. J. 1945, 1, 403.

20. Acher, R., and C. Fromageot. The relationship of oxytocin and vasopressin to active proteins of posterior pituitary origin in The Neurohypophysis, H. Heller, Ed. New York, Academic Press, 1957.

21. Nibbelink, D. W. Paraventricular nuclei, neurohypophysis and parturition. Amer. J. Physiol. 1961, 200, 1229.

22. Holland, R. C., B. A. Cross, and C. H. Sawyer. Effects of intracarotid injections of hypertonic solutions on the neurohypophyseal milk-ejection mechanism. Amer. J. Physiol. 1959, 196, 791.

23. Cross, B. A. Suckling antidiuresis in rabbits. J. Physiol. (Lond.) 1951, 114, 447.
24. Pickford, M. Factors affecting milk release in the dog and the quantity of oxytocin liberated by suckling. J. Physiol. (Lond.) 1960, 114, 447.

25. Andersson, B. Some observations on the neurohormonal regulation of milk-ejection. Acta physiol. scand. 1951, 23, 1.

26. Baisset, A., G. Lesbre, and P. Monstratruc. Recherches expérimentales sur la sécrétion oxytocique. Path. et Biol. 1961, 9, 1447.

27. Theobald, G. W. The separate release of oxytocin and A.D.H. J. Physiol. (Lond.) 1958, 149, 443.

28. Dicker, S. E. Possible independence of oxytocin and vasopressin secretion in the human being. J. Physiol. (Lond.) 1959, 147, 25.

29. Chaudhury, R. R., and G. F. Joplin. Preliminary observations on the release of oxytocin and vasopressin in human subjects. J. Endocr. 1960, 21, 125.

30. Bisset, G. W., and J. M. Walker. The effects of nicotine, hexamethonium and ethanol on the secretion of the antidiuretic and oxytocic hormones of the rat. Brit. J. Pharmacol. 1957, 12, 461. 